\title{
On Procurement Management in China's Big State-owned Enterprises
}

\author{
Liu Xuexin \\ College of Business Administration, Capital University of Economics and Business \\ Beijing 100070, China \\ liuxuexin@cueb.edu.cn
}

\begin{abstract}
Keywords: procurement; bidding management; State-owned enterprises; risk mechanism;
\end{abstract} corruption

\begin{abstract}
In China's big state-owned enterprises the system of procurement for project was firstly adopted since 1984, which has made solid progress in establishing a construction market with the principles of openness, fairness and justice. The Bidding Law of the People's Republic of China was passed in 1999, which provides a legal basis for the full implementation of the institutionalized bidding management. The bidding system can solve the problem of information asymmetries during the transaction, reduce the procurement costs, and effectively prevent the corruption. Therefore, more and more big state-owned enterprises and projects have adopted bidding management as a major method of procurement. Currently, procurement management of most big state-owned enterprises in China is still in its infancy, which is adopted only in some limited scope of materials purchasing process, and the management is still in its initial level. This paper investigates the current status of procurement and bidding management in China's big state-owned enterprises, and analyzes the existing problems in details, and provides some corresponding suggestions and management measures both for the state-level policy and firm-level management.
\end{abstract}

\section{The current status of procurement management of big state-owned enterprises in China}

On the whole, big firms in China have been applying bidding system to project constructions and material procurement, and are developing their own bidding management systems. It has produced certain commendable fruits: the bidding activities are becoming popular, the quality of bidding is getting improved, and the information of bidding is making public in transparent conditions. However, on the basis of an investigation into big firms' bidding activities and their bidding management, it is still in its infancy; and bidding is adopted only in some limited scope of materials purchasing process of enterprises, and its level is also not high; currently only a few enterprises in China have set up the whole process of online bid platform.

In addition, bidding management is not normative, though the State and relevant departments have launched The Bidding Law of the People's Republic of China (August 1999), Measures for the Qualification Accreditation of the Bidding Agencies of Engineering Construction Projects (January 2007), Measures for Handling the Complaints concerning the Tendering and Bidding Activities for Engineering Construction Projects (June 2004), Measures for the Bid Invitation and Bid Tendering for Construction and Engineering Projects (August 2003), Measures for the Administration of Bid Invitation and Tendering for Bid of the Technological Innovation Projects of the State (October 2002), the Interim Measures for Announcement of the Records on Illegal Tendering and Bidding Acts (June 2008), the Interim Measures for the Release of Invitations to bid (July 2000), Administration Measures for the Determination of the Qualification for Bidding Agencies of Investment Projects Financed by the Central Government (September 2005), etc. relevant laws and regulations, there still needs necessary measures to regulate the behaviors of firms in practical works. Meanwhile, the levels of bidding management in big firms are different, ranging from bad to excellent. For example, a few firms like China Mobile Communication Corporation, China Telecom, China Unicom, State Grid and China Huadian Corporation have set up bidding management 
platform in their websites, but the majority of domestic enterprises still do not set up an online bidding management platform.

\section{The Main Existing Problems for Procurement Management in Big State-Owned Enterprises}

From a specific perspective, big firms in China have the main existing problems in the bidding management as follow:

\section{A. Imperfect mechanism of bidding management institutions}

Firstly, the tendering exercises of most firms are charged by different operating departments according to the contents of projects, the operating procedures are different; secondly, the actual staff mainly come from economic and technical personnel, who have no professional knowledge of bidding management; thirdly, there is not a control and evaluating mechanism which unifies symmetrically duties, rights and interests, therefore the accountability system is rather good, the evaluation and incentive is not enough. Meanwhile, functions of enterprise supervision department and authorities concerned are not clearly defined against each other, they may intervene in bidding, impose some commendatory firms for firms of tend offer, appoint some agency for bidding, and even exceed their duties and invite enterprises' bids by themselves. They may exercise non goodwill management, and concoct various pretexts to collect ride fees, such as policy consulting fee, examination fee for price bottom of a bid, etc.

\section{B. Incomplete decision-making mechanisms}

First, bid evaluation committees mainly consists of administrative leaders and department administrative staff, which cannot ensure the requirement that the proportion of technical and economic experts should exceed two thirds of the total number, thus evaluation of bid becomes a kind of executive decision.

Second, induced evaluation of bid; while evaluating a bid, the director of the committee often expresses some "instructive" suggestion that is formed on some tenderee's opinion, then the committee grades the bid or votes for it, the evaluation are not fair and impartial.

Third, evaluating and tendering are disconnected; the interval between evaluating and tendering is not clearly defined in The Bidding Law of the People's Republic of China and relevant regulations. In practice, many enterprises usually separate evaluating procedures from tendering ones, and rarely award the bid on the spot; it has low transparency, and may have some fraud among the procedure.

\section{The lack of mechanisms for risk management}

Price risk. First, suppliers and relevant staff may collaborate together and leak the base price, thus the firms suffer loss among their procurement practices.

Quality risk in procurement. Suppliers have supplied some goods whose quality can not meet the demand, so that the enterprise can not ensure normal production and suffer certain economic, technical, personal safety and reputation losses.

Contract risk. first, some articles of contracts are vague; constraint to the liability for breach of contract is simplified, and is only a verbal agreement or a gentleman's agreement; the proportion of authentication, notarial contracts is rather low. Second, illegitimate contract practices, for example, the contractor may bribe the buyer, may attempt to get the lowest bid of enterprise's procurement, or provide some false preferential treatment.

Acceptance risk. Suppliers may give short weight, or take substandard products as fine products; the assortment of goods is incorrect and cannot meet the demand.

\section{Defective management system, lack of normative procedure and process management}

By means of the investigation into big firms, it is found that some firms have made relevant bidding management measures which has their own characters according to The Bidding Law of the People's Republic of China; while a good portion of firms still have not created a bidding 
management method that is based on their own situations, thus lack a total normative process to control the bidding management practices.

\section{E. The unreasonable delimitation of management approval power between parent-subsidiary companies}

For most big firms, head office and the rest of the company usually have different items of material procurement, in many cases the procurement should be completed by local branches for the ethnic customs, economic and regional factors are taken into consideration. Therefore, a corresponding delimitation criterion is useful to achieve a rational allocation of procurement tasks in which the head office should focus on some items of procurement and the local branches should fulfill others and know how to deal with special items by communicating with their head office.

\section{F. The partial expert database and its defective management}

First, the criterion threshold is too high and few experts are included. The expert database has few members, and that can meet the demand of evaluation of bid. The main reason for that are the excessive requirements of experts' qualifications. The present expert database, under the condition of an increasing scale of procurement, can not meet the demand of evaluation of bid for that there are more and more projects that are rare and not in popular demand and require complicated technologies.

Second, scattered expert resources require a successful integration. Many organizations, like social intermediary agencies, departments of education, heath care, transportation and water conservancy, have built up their own expert databases, but the frequency of using experts is rather low, and it causes much waste of expert resources without social transverse connect institution.

Third, variable expert quality will exert a bad influence on evaluation. The experts have mixed quality. Meanwhile, there are no effective measures to constraint the experts and lacks of award and penalty mechanisms.

\section{G. Lack of supervision system}

Imbalance supervision system and incomplete supervision mechanism make supervision ineffectual. It can be seen as follow: first, there is not a specialized supervision organization for firms, or the existing supervision department does not have staff specialized in supervision, and the members of bid inviter group, who have poor knowledge about relevant laws, regulations and policies, are provisionally recruited from different departments, and cannot handle the practical problems effectively. Second, there is not a scientific and strict bid management system. Therefore, in practice there is no Legal basis to depend on when such problem appears, and either party dodges their responsibilities. Third, the cost of supervision is rather high. The staffs of some projects are both "athletes" and "referees", to an extent which easily slackens supervision work. Fourth, firms usually regard supervision work as a kind of constraint, and do not inform the supervision staff of the bidding. Then firms do not attach much importance to bidding, the supervision becomes lax and the project supervision loses constraint to bidding. In the processes of bid opening, evaluation and awarding the firms lose their vigilance to project supervision, thus some unfair and unjust phenomena appear. For example, some firm does not get the bidding items approval according to stipulations, but issues bidding announcements and sell bid documents; and some firm, though its bidding is approved, does not organize bid invitation in accordance with the approval requirements. Some bid inviter does some tricks on bid information issue; the bid inviter does not issue the bid announcement of the project that should undergo public bidding according to stipulations in the media specified, or imposes restrictions on the scope of bid information distribution. Some bid inviters practice nonstandard bidding evaluation. The method of bid evaluation and award is determined after the time that all the bids are received but not before the deadline of submitting bids, and they have no detailed regulations of evaluating and awarding bid so that these procedures have no objective criteria and the result is rather arbitrary. Some bidding evaluation staff has poor quality and cannot impartially evaluate bid and scientifically award bid. 


\section{Suggestions for improving procurement management of big state-owned enterprises in China}

The key control points of bidding management of big firms include establishment of administrative rules and organization structuring, reasonable power delimitation, improvement of supervision mechanism, and reinforcement of supervision work, etc. With clear and definite management rule and several key control points, some specific measures can be put into practice to improve the bidding management of big firms. It goes as follow:

\section{H. Enhancing the work of promotion and supervision and inspection, implementing strictly the state bidding regulations and the bidding process}

The promotion of the bidding law and regulations should be strengthened by various ways, thus a sound public opinion environment can be created, and departments in charge of enterprises, the owner units, the bidding firms can fully realize the importance of standardization of bidding behaviors, and the importance of fostering a construction market with the principles of openness, fairness and justice, which can urge them to handle practical affairs according to law. At the same time, the big firms should emphasize the management of key part of bidding activity and strictly abide by the legal procedures in practice.

\section{Normative management of bid invitation agencies}

Big firms should select professional bidding agencies which exhibit characteristic features of specific area of expertise, good professional quality, strong service awareness, great industry credibility and operation in accordance with laws and regulations. They should constantly strengthen the fostering and management of bidding agencies, choose a bidding agency and sign a contract of good faith cooperation with it to establish a cooperation relation on the basis of careful investigation and detailed assessment. The agencies should strictly make bid documents in accordance with the bidding law and regulations and abide by the existing normative documents. The bid documents should exhibit the principles of openness, fairness, justice, honesty and credit-worthiness, do not contain some unreasonable terms to restrict or exclude potential bidders, do not include some provisions that discriminate some potential bidder, or include some requirements that ask bidders or potential bidders to provide information that has no relation with execution of the contract.

\section{J. Enhancing the construction of expert database and the management of experts of bid evaluation}

The establishment of industry expert databases should be in accordance with the relevant stipulations and provisions of The Bidding Law of the People's Republic of China, and there should be some clear and definite criteria for the qualifications bid evaluation experts, which should be strictly practiced to examine experts' qualifications; and the administrative measures and working system of bid evaluation experts should be formulated, in which experts should attend training and checking at a regular interval, and have a dynamic management and assessment; the structuring of expert databases should be constantly optimized so that some experts who have certain strong points can be included into database and some incompetent experts can be excluded at any time. The network of management system of bid evaluation experts should be developed and put into practice, so that the information-based management can be adopted, like the online management of bid evaluation experts, selection from online databases, automatic generation of bid evaluating records and performance assessment, etc. The stipulations and laws should be explained and publicized to the experts when they have opportunity to evaluate bid so that they can know clearly about the principles and the discipline of bid evaluation.

\section{K. Adopting credit management to develop firms' normative behaviors}

Credit management can be adopted as an important way of bidding supervision and to regulate bidding firms' behaviors. First, the regulations of credit rating management should be worked out, firms' credit file can be used as an important indicator for the qualification checking and other bidding procedures, so that firms will attach great importance to their social credit rating and form senses of honesty in practice. Second, a unified and normative credit rating system should be established, in which firms' products and service quality that integrate market management and field management together will serve as the key checking points, and combine with the credit rating from 
administration, customs and banking system to formulate a comprehensive, complete and universal firm credit file. Third, a unified credit information sharing platform should be established, so that different industries can share, recognize mutually and exchange the credit information; meanwhile, the result can be announced to the public to further enhance control to firm credit.

\section{Strict prequalification check}

Market access management should be strengthened by strictly reviewing firms' qualifications. Some bidding projects, which exhibit the characteristic features of large amount of investment, intensive technology, long construction period, high quality requirements, and great influence in public safety and environment protection, will not only cause enormous economic losses, but bring endless future troubles if their builders' qualifications are not closely examined. Therefore, the qualification review should be treated with extreme prudence and the review scope should be broadened. First, the bidders' qualification ratings should tally with the project requirements, which include the following items: they have the capability to undertake the contracted projects or not, what about their performance in the past, their credit information, and the project manager's and the technical leader's relevant certificates. Second, the bidder's professional technical structure, engineering qualification, the number of its technicians should meet the project requirements, its total quality control system should work well, its technicians have powerful control over safety and quality accidents, and are skillful at new processes and new technologies. Third, its main mechanic equipments should satisfy the project, including its number, advancement, comprehensive support capabilities. The bidder firms should provide all specific information according to the bid invitation and attend the bidding only after its qualification passes the systematical examination.

\section{Adopting scientific methods of bid evaluation}

The key points of reformation of bid evaluation criterion system are as follow: the price competition of bidding should be shift to the competitions of firms' management and their technological innovation capability; and the suppliers' and contractors' achievements, their social credit ratings, the capability of resource integration management and technological innovation capability should be adopted as the principal criteria of bid evaluating and awarding. Having taken into consideration of the multiple factors such as the practical conditions of bidding projects, the different types of construction, various types of goods and services, the bid inviter's financial situation, the intended purpose of bid, the level of staff and management level, the bidding agencies should design the specific items of bid document, set up the grading norm and weight value of each item, and select the best bidder to the bid inviter in the light of the principles of openness, fairness and justice. The work also exhibits the quality and level of the bidding agencies.

\section{N. Establishing a modern bidding information system and an electronic bidding platform}

Bidding is a complicated work, which needs a great amount of preparation work, especially the collection and analysis of information. The great amount of data and information should be processed by computer with the aid of establishment of databases and data processing system that needs professional computer operators and powerful software and hardware. The firms should increase the investment of necessary hardware and software, and build up bidding websites and bidding information centers, and use the modern management method to ensure the success of bidding activities.

The big firms should actively explore and set up electronic bidding platforms to improve the degree of bidding procurement transparency. Whether the bidding information is transparent or not is the prerequisite of ensuring a bidding activity with the principles of openness, fairness and justice. An electronic bidding procurement platform is a systematic project, which involves the improvement of laws and policies, the support of firms and bidding agencies. Currently China should give great impetus to the electronic bidding procurement work, speed up its legislative work, and improve the bidding law and support stipulations so that the system can provide legal support to the bidding procurement and can serve the government and firms better.

The practice of bidding system can break the market monopoly and build up a trade mechanism with the principles of openness, fairness and justice so that it can further improve the socialist market 
economy, and play an important role in the development of economy. Big firms should unflinchingly implement the stipulations of bidding management, which is the cornerstone of bidding management of big firms. Explicit purposes, complete regulations and effective supervision will guarantee a reliable bidding activity. Strict management measures, normative process control, optimal procedures and basic management are the foundation of bidding quality. The fostering and development of bidding market is a long-term and arduous task, which needs efforts in all directions. According to the demand of perfection of the socialist market economy, big firms should improve the bidding management, and provide a good service for financial investment and social economic construction.

\section{Acknowledgement}

This paper is supported by Humanities and Social Sciences Planning Fund of Chinese Ministry of Education (08JA790087), Beijing Municipal Natural Science Foundation (9112003) and Beijing Social Science Foundation (12JGA007).

\section{Reference}

[1] Ahmad Irtishad. Decision-support system for modeling bid/no-bid decision problem. Journal of Construction Engineering and Management.1990,116(4):595-608.

[2] D.K.H.Chua. Key Factors in Bid Reasoning Model. Journal of Construction Engineering and Management.2000:No.10.

[3] FIDIC. Guide to the use of FIDIC conditions of contract for works of civil engineering construction.1989: Switzerland.

[4] Friedmna L. Competitive-bidding strategy. Operations Reseach.1956, 82(4):104-112.

[5] Gates M. Bidding strategies and probalilities. Journal of Construction Engineering and Management.1967,93(1):75-107.

[6] Hapman CB, Ward SC, Bennel JA. Incorporating uncertainty in competitive bidding. International Journal of Project Management.2000,18:337-347.

[7] Lawrence Friedman. A Competitive-Bidding Strategy [J]. Operational Research. Vol. 4, No.1, February 1956, pp. 104-112.

[8] Martin Skitmore. Bid-Spread.Journal of Construction Engineering and Management. 2001:No.2.

[9] McAfee, R.P. and McMillan, J. Bidding Rings [J]. American Economic Review, 1992, 82:579599.

[10] Myerson, R. B. Optimal Auction Design [J]. Mathematics of Operations Research, 1981, 6:5873.

[11] Porter R.H., Zona J.D. Detection of bid rigging in procurement auction[J]. Journal of Political Economy, 1993, 101(3):518-538.

[12] Richard Engel, Brecht-Wiggans. The effect of regret on optimal biding in auctions. Management Sciences.1989:685.

[13] Riley, J. G. and Samuelson, W. F. Optimal Auctions [J]. American Economic Review, 1981, 71:381-392.

[14] Seydel Johb, Olson David. Bids considering multiple criteria. Journal of Construction Engineering and Management.1990, 116 (4):609-623. 